\title{
Keeping it Safe: Energy Conservation=More Money ${ }^{1}$
}

Mary N. Harrison²

Heating and cooling your home uses more energy and takes up more money than any other system in your home. No matter what kind of heating, ventilation, and air-conditioning system you have, you can save money and increase comfort by properly maintaining the equipment.

\section{Heating Tips}

- Clean or change your filters once a month.

- Set your thermostat as low as is comfortable. In cooler weather, instead of turning your thermostat up, put on a sweater and an extra pair of socks.

- Open your curtains or draperies during the day to let in the warm sun and close them at night.

- Make sure your home is properly insulated and has good ventilation.

- Weather-strip any cracks or openings around your windows and doors.

- Make sure your furniture isn't blocking vents and outlets for warm air.

\section{Lighting}

- Turn off lights in rooms you are not using.

- Use new energy efficient bulbs in your lamps.

\section{Hot Water}

- Set your water heater thermostat to $120^{\circ}$ Fahrenheit.

- When washing your clothes, use the appropriate load setting. Don't wash a small amount of clothing on the large load setting. (Correct settings also get clothes cleaner.)

- Clean the lint screen in your dryer each time you start a new load.

- Install a low-flow showerhead and low-flow faucets.

- Repair leaky faucets quickly.

- Use cold water when you run your garbage disposal.

1. This document is FCS5233-034, one of a series of the Department of Family, Youth and Community Sciences, Florida Cooperative Extension Service, Institute of Food and Agriculture Sciences, University of Florida. Publication: May 2002. Revised: December 2005. Please visit the EDIS Web site at http://edis.ifas.ufl.edu

2. Mary N. Harrison, professor, Department of Family, Youth and Community Sciences, Cooperative Extension Service, Institute of Food and Agricultural Sciences, University of Florida, Gainesville, 32611.

The Institute of Food and Agricultural Sciences (IFAS) is an Equal Opportunity Institution authorized to provide research, educational information and other services only to individuals and institutions that function with non-discrimination with respect to race, creed, color, religion, age, disability, sex, sexual orientation, marital status, national origin, political opinions or affiliations. U.S. Department of Agriculture, Cooperative Extension Service, University of Florida, IFAS, Florida A. \& M. University Cooperative Extension Program, and Boards of County Commissioners Cooperating. Larry Arrington, Dean 
- When you wash your dishes, fill the sink with

hot, soapy water instead of letting the water run.

\section{Air Conditioners}

- If you have ceiling fans, use them! They can make your room very comfortable and use much less energy than running the air conditioner all the time.

- Set the thermostat at 78 degrees or higher. Wear light clothing to be comfortable and save energy.

- Don't put lamps or televisions near your thermostat. These appliances give off heat that the thermostat will register.

- Check the filters once a month. Change them when they get dirty.

- If you have a window unit, make sure there are no holes in the seal between the unit and the window frame-cool air could seep out. 